\title{
A Graphostylistic Analysis of Selected Poems in Remi Raji’s Web of Remembrance
}

\author{
M. O. Ayeomoni ${ }^{1}$ \\ ${ }^{1}$ Department of English, Obafemi Awolowo University, Ile Ife, Nigeria \\ Correspondence: M. O. Ayeomoni, Department of English, Obafemi Awolowo University, Ile Ife, Nigeria. \\ E-mail: ayestyle@yahoo.com
}

Received: June 25, 2012

Accepted: August 7, $2012 \quad$ Online Published: September 26, 2012

doi:10.5539/ijel.v2n5p101

URL: http://dx.doi.org/10.5539/ijel.v2n5p101

\begin{abstract}
The study undertook a graphostylistic analysis of Remi Raji's poems in the anthology entitled Web of Remembrance. The selected poems in the Anthology include "Bound to remember," "Malediction for maximum ruler”, “An African voting games”, "st. clinton's song” and "Light must break”. The poems were analysed from the perspective of the linguistic framework of graphostylistics following Halliday (1971) and Mukarovsky (1964), concepts of foregrounding and deviation. The study adopted graphological deviational approach to analyse the six texts across various graphological tactics of punctuation, capitalization, spacing, hyphenation and internal norms. It is discovered that the language employed in the Web of Remembrance is essentially centred on graphostylistics. The selected poems for the study manifested deviations at various graphological tactics (punctuation, capitalization, hyphenation, spacing and internal norm). These graphological devices were used by the poet to capture the messages of the poems which are basically on condemnation and apprehension of the evils, atrocities, oppression and injustice perpetrated by the erstwhile African political leaders, both at home and abroad and advocates the need for revolutionary change. The study showed how graphostylistics has been effectively manipulated to communicate in Web of Remembrance as demonstrated in the six selected poems from the anthology. The study proved that graphostylistics is a reliable linguistic tool for the study of literary texts, particularly, the poetic genre. It equally demonstrated that graphological components or devices of language could illuminate, to a large extent, the communicative goals of a poetic genre as an instance of language use.
\end{abstract}

Keywords: graphostylistics, deviation, poetic genre, foregrounding, graphological tactics

\section{Introduction}

This study undertakes a linguist stylistic analysis of five poems from Remi Raji's Webs of Remembrance: Bound to remember; Malediction for maximum ruler; An African voting game; St. clinton's song; Light must break using the framework of graphological deviation as a basis The study, therefore, attempts the analysis of Webs of Remembrance as a collection of poems informed by the revolutionary aesthetics from the perspective of linguistic stylistics.

The study locates the values of linguistic analysis of poetry and claims that it cannot be brushed aside or ignored in contemporary practice (Fowler, 1971; Chatman, 1965; Osundare, 2003; Ayeomoni, 2005 among others). Moreso that the major aim of Linguistic Stylistics is to study the language use in texts with the aim of relating it features to its artistic functions (Leech \& Short, 1981). Then the language use is always informed, nurtured and textured by different and interacting mappings, which Lawal (2003: 155) sees as involving the linguistc, situational, psychological, social, sociological and cosmological contexts. Ayodabo (2003: 136) reinforces this view when he posits that the style is really only definable in terms of the operations carried out by the producers and receivers of texts.

\subsection{The Implied Poet: Remi Raji}

Remi Raji is the implied name of Aderemi Raji Oyelade, born in Ibadan, Nigeria. He has won both national and international recognitions for his writings. His volumes of poetry include A Harvest of Laughter (1997), (2003), Web of Remembrance (2001), Shuttle Songs America, A poetic Guided Tour (2003) and Love Song for my Wasteland (2005). Remi's works have been translated into French, German, Ukranian, Swedish and Catalan, 
Currently, a Research Fellow at the Centre of African Studies, Cambridge University. He is a joint winner of the 1977 Association of Nigerian Authors/Cadbury Poetry Prize with his collection, a Harvest of Laughter, and a winner of the Association of West African Young writers' VOCA Award for Best First Published Book of the Year 1997. Remi Raji is currently the National Coordinator of PEN Nigeria Centre. He teaches literature in the Department of English, University of Ibadan, Nigeria.

\subsection{The Synopsis of the Webs of Remembrance}

In Webs of Remembrance, Remi Raji launches a ferocious attack on the political dictators who thrive by social injustice, oppression, and the experience of being dehumanized by the weapons of state in the period of military dictators. Therefore, Webs of Remembrance is indeed, an aesthetic ritual of forgetting, which in itself, a form of functional remembrance. This work documents the physical and spiritual loss associated with the condition of being exiled in detention. So, Webs of Remembrance is a deliberate attempt to move from anguish to hope and from criminal silence to freedom.

\subsection{Linguistic Approach: A Review}

The study is based on the approach of Linguistic Stylistics which has been tested and adjudged reliable for analyzing and interpreting literary texts. Linguistic Stylistics incorporates linguistics and literary criticism in order to match the objectivity of the former with the intuitive characteristics of the latter. Thus, the approach does not deny the fact that intuition plays a major role in the analysis and interpretation of literary texts. It only emphasises that the practitioner's intuition must be explicit to their audience and discipline it through the linguistic description of the language use in texts. So, the intuitive analysis will not only indicate socio-psychological experiences in literary text, but can also help to create awareness about the internal patterns of language in the text. Adegbite (1994), says: "Linguistic Stylistics, also, refers to the linguistic study of the language patterns manifested in the literary text”. And Halliday (1973), sees Linguistic Stylistics as:

the description of literary texts by methods derived from general linguistic theories and within the frame work of description of the language in question, and the comparison of such texts with others by the same and different authors in the same and in different genres.

Thus the merit of Linguistic Stylistic approach lies in the ability of the production to carry out the description of language patterns in texts while relating such patterns to the artistic functions objectively. Linguistic Stylistics, according to Halliday (1976), is an application; it is the only way to ensure the theoretical validity of a statement. Hence, Haliday says, in (218), that: "Stylistics is the description of literary text by method derived from general Linguistic theory and within the frame work of a description of language in question..."

Chomsky (1970), states that linguistics is the scientific study of language and by this, he views that linguistics is a science designed for the study of natural language. Short (1982), uses the term, Literary Linguistic Stylistics to refer to the studies of literary style from linguistic perspective. Turner (1973: 7), says, "it is that part of linguistics, which concentrates on variation in the use of language often, but not exclusively, with special attention paid to the use of language in literature." Dare (1991: 59), further explain that "Stylistics is a discipline devoted to the systematic, methodical or scientific study of style." Ayeomoni (2004), notes that linguistic stylistics occurs in Literature alongside other terms as "Stylistics", "Modern Stylistics", "the New Stylistics" and "Literary Linguistic Stylistics". Hence, he defines linguistic stylistics as "an analytical approach that helps readers to objectively study both literary piece and non-literary materials” (Ayeomoni, 2004: 177).

\subsection{Linguistic Frame Work}

\subsubsection{Deviation as a Linguistic Device}

According to Mukarovsky (1932), a Professor of aesthetics of Chicago University at Prague, says foregrounding is connected with deviation from linguistic and literary norms. "Deviation", then, means a term in stylistics which is a deautomatization of familiar linguistic and literary norms. This presupposes that there are certain items that have become familiar and automatized. So, foregrounding simply means violation of the automatized scheme. This summarily implies that foregrounding is deviation and deviation is concomitant with de-automatisation. In a similar tone, Halliday (1964), says that the term "foregrounding is prominence" that is motivated. This implies that it is not everything that stands out in a text that is foregrounded. This is a departure from Mukarovsky's position, that any linguistic item that stands out or attracts attention is foregrounding. Halliday, in this paper, argues further that such prominent structures or items could be labelled foregrounding only if they contribute to the total or overall meaning of the text. If they do not, according to him, they seem to lack motivation, and this implies that such items are not prominent. This then presupposes that there are two forms of foregrounding, which are: 
a. Motivational prominence

b. Unmotivational prominence

The motivational prominence is connected with items that are consciously injected into the text for semantic purposes, while the unmotivational prominence is unconsciously injected and meaning may not be inherent in it. So, the concept of "foregrounding", occupies a central place in Linguistic Stylistic analysis, hence Ayeomoni (2004: 180), similarly observes that the concept of foregrounding is taken up by Mukarovsky (1932), when he says that foregrounding can be related to the factor of deviation from linguistic norms.

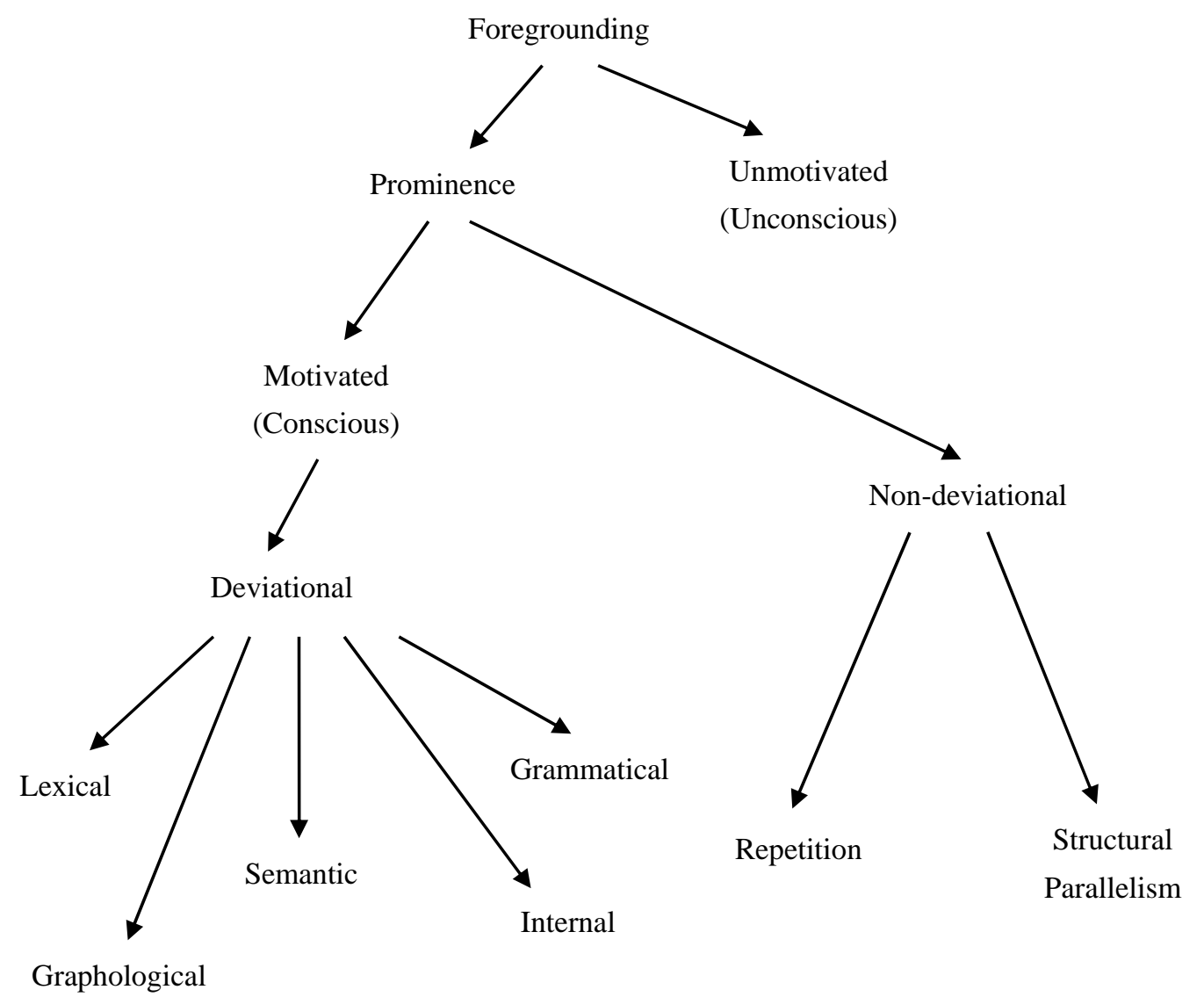

The explanation here is that deviation could occur at the levels of graphology, lexis, syntax, semantics, morphology and internal. But this paper focuses on the graphological form of deviation.

\subsection{Graphological Deviation}

This is a form of deviation which concerns the breaking of rules resulting in non-usage of punctuation marks, (such as, comma, full-stop, question mark, quotation marks, capitalization, violation of an established norm or the use of emblematic features, and so on. Poetry, which is the focus of this paper, is marked off from other forms of writing by graphological means in that it often has lines which do not run out to the right hand edge of the page and in most cases, begins all lines with capital letters, and has specific structure that abides by conventional agreement of the genre. Anything contrary to this could be termed a deviation. A good example is Bound to remember in Remi Raji Webs of Remembrance as indicated below:

no water runs where the Niger flows

no fish swims where the Benue berths

my spirit is grieved, my grief is long like the rivers

i will not forgive I will not forget

I will be like God vengeance of truth 
I will be thunder in the kidney of liars...

Graphological deviation occurs in the above extract at the level of non-usuage of capitalization at the beginning of each line, lack of punctuation, and structural deviation from the norm of writing in poetry. This has implication for both semantic and internal deviations.

\subsection{Aim and Objectives of the Study}

The study aims at conducting an inquiry into the use and functions of graphostylistics in Remi Raji's poetry. It has the following objectives:

to identify and quantify the various forms of graphological tactics employed in the anthology Webs of Remembrance; and show how the identified graphological tactics have been deployed to aid objective analysis and interpretation of the texts.

\subsection{Method of Data Analysis}

In line with the empirical goal of Linguistic Stylistics, the anthology, Webs of Remembrance, by Remi Raji is subjected to thorough empirical analysis at graphological level using the linguistic items of punctuation, capitalization, hyphen, lower cases of letters and internal norms.

\section{Analysis}

\subsection{Graphological Analysis}

\subsubsection{Non-uasge of Capital Letters}

In Remi Raji's Webs of Remembrance, one of the most prominent deviational devices of the poem is graphological deviation. In Bound to Remember, for instance, the poet begins the poem by establishing a local norm through representation of stanzas with two lines but goes further to violate this norm. Other stanzas such as the second stanza, has four lines, the fourth stanza has three lines, the sixth and ninth stanzas have a line while the eighth stanza has ten lines. This inconsistence in the numbering and grouping of the stanzas is indicative of the poet's view of socio-political instability, imbalance, inequality, anarchy, agony, pain, oppression, and abnormality in the society that he captures in the poem.

Moreover, the poet foregrounds this poem graphologically by violating the structural internal norm of poetry; he introduces each line in small letters. He also fails to use capitalization where convention calls for it. For instance, stanzas one and two of the poem as shown below show non-usage of capital letters at the initial lines of the poem:

$$
\begin{aligned}
& \text { no water runs where the Niger flows } \\
& \text { no fish swims where the Benue berths } \\
& \text { my spirit is grieved, my grief is long like the rivers } \\
& \text { i will not forgive I will not forget } \\
& \text { i will be like God vengeance of truth } \\
& \text { i will be thunder in the kidney of liars... }
\end{aligned}
$$

Furthermore, the poet frequently deviates graphologically to vividly capture his message in Malediction for a maximum ruler, An African voting game, St. cliton's song, and Light must break . The poet consciously violates the rules of using capitalization in poetry at the beginning of each line in order to reduce the image of the political leaders who perpetuate socio-political anomalies. Most of the lines begin in small letters. This shows that the poet sees the political leader as individuals that do not deserve honour, so, he uses this linguistic tactics to reduce the personalities and to show that they do not deserve respect. Consider the following extract in the An African voting game.

$$
\begin{aligned}
& \text { And the ballot boxers spring } \\
& \text { into the ring again } \\
& \text { flyweight, superweight, paper- } \\
& \text { weight of bantam } \\
& \text { bricks of tricks } \\
& \text { ballot boxers in numbers game } \\
& \text { failed matadors who bite }
\end{aligned}
$$




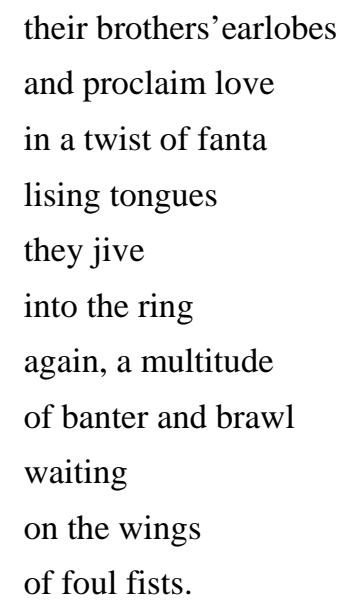

In the above extract, each of the lines begins with lowercases of letters through which the poet exposes the various political influences and vices among the politicians during electioneering period in Nigeria that is meant to be conducted in a free and fair atmosphere. The poet pictures an image of situation where citizens' mandates are being upturned in the lines below:

$$
\begin{aligned}
& \text { and the ballot boxers spring } \\
& \text { into the ring again } \\
& \text { flyweight, super weight, paper- } \\
& \text { weight of bantam... }
\end{aligned}
$$

But because of the socio-political injustice, and love for power, and greed of our political leaders, the subsequent lines show a situation where politicians come with pretence claiming to have the love and interest of the people at heart as manifested in the choice of words below and use of lowercases of letters without any use of capital letter as seen below:

$$
\begin{aligned}
& \text {...ballot boxers in numbers game } \\
& \text { failed matadors who bite } \\
& \text { their brother's earlobes } \\
& \text { and proclaim love } \\
& \text { in a twist of tanta- } \\
& \text { listing tongues... }
\end{aligned}
$$

These politicians, pretended to love the people, to capture this message clearly, the poet foregrounds the structure by deviating graphologically from the poetic norm of writing (small) letters usage to begin each of the lines. Also, a close look at the structure of the first stanza of the poem, the number of items occupying a line diminish downwards up to the last lines of the stanza. The poet uses the structure to reveal how the social ethics diminishes due to the unjust activities of our political leaders.

In similar vein, Remi Raji adopts the non-usage of capitalization as an instance of graphological deviation in "St Clinton's song" to remind us of Clinton's sexual scandal at the time he was president of the United State of America, when he was accused of having a sexual affair with lady Lewinsky. This sexual immorality informs the use of small letter to start the name of Clinton in the poem: "clinton's song”.

\section{if I were clinton}

i would clinch one more victory

in the lewinskian lap of tender nights

\section{if I were clinton}

i would bite the apple again

and blame saddian the serpent of irag

i would blame castro the eunuch of Havana. 
In the above extract, the poet sees himself as an ordinary person among the lower class with Clinton who is a bourgeoisie and belongs to the upper class but has reduced himself to the background because of his immorality. This informs the use of pronominal item "I" in small letter, representing the persona and small letter "c" in place of the capital - equivalent for Clinton. This tactics reinforces the fact that Clinton has reduced himself to nothing as his reputation and personality have been jeopardized.

The same trends of graphological deviation continues in the "Bound to remember" which shows the relationship between the persona and the subject matter. The poet depicts the theme of contrast, disagreement, hatred, oppression; inhumanity, pain, etc. between the persona (through the pronominal item "i”) and the target audience as follows:

$$
\begin{aligned}
& \text {.. i see rodents still } \\
& \text { i see reptiles in new skins } \\
& \text { i see bats flying above the flood. }
\end{aligned}
$$

\subsubsection{The Use of Graphological Hyphenation Tactics}

In a similar vein, Malediction for a maximum ruler is a poem that shows instances of graphological deviation. This poem like "Bound to remember" discusses the activities of the political leaders and their various engagements in socio-political vices. In stanza three of this poem, the poet makes reference to some African political leaders who have treated their citizens like slaves and mismanaged their power and authority unjustly. The poet uses hyphen to compound and link the names of the various despotic African leaders together who are peculiarly known to have threatened their citizens and mismanaged the power, economy and resources of their countries as manifested in these lines:

$$
\begin{aligned}
& \text { oh yes, I tried to believe } \\
& \text { that his bones now simmer } \\
& \text { in Dante's sulfuric region } \\
& \text { broiling in tutorial vice } \\
& \text { of Amin-Bokassa-Doe-Sees Seko Schoool } \\
& \text { they say the emperor is dead } \\
& \text { but his symbols dangle } \\
& \text { dangerously... }
\end{aligned}
$$

These African leaders include: Idi-Amin of Uganda, Samuel Doe of Liberia and Mobutu Sese Seko of Republic of Congo. These are sets of leaders who have ruled and inflicted pains, agony, war, oppression, inhumanity, repression, anarchy and terror on their people. The poet foregrounds them by compounding these personalities who possess similar qualities (Amin-Bokassa-Doe-Sese-Seko), even when writing convention does not require it.

Moreover, Remi Raji also adopts this feature of graphological deviation in An African voting game to foreground the moral decadence of our political leaders. Right from the title of the poem, the poet intentionally represents "African" with small letter "a" as in "african". This instance of deviation is to show that what happens in Africa is nothing to write home about. The poet paints an image that Africa is one of the continents where election cannot be conducted with a clear mind of electing the right candidates but would eventually be influenced by minority; it is a place where democracy has no meaning as reflected below:

$$
\begin{aligned}
& \text {...or if the reference throws a deadly fist } \\
& \text { and gives a casino man the knife to stab the Bank? } \\
& \text { or if tongues bite themselves in brawls? } \\
& \text { or if tribes tear the ribs of Peace? } \\
& \text { or if... }
\end{aligned}
$$

The above stanza is written rhetorically to capture the persona mood. "Bank" and "Peace", are presented in capital letters, this is a clear case of deviation as "Bank" in this respect, means a financial institution while "Peace" means (a period) of freedom from war and violence, especially, when people live and work together happily without rancours. Furthermore, the second line above foregrounds the word "bank" to mean the ballot boxes and the "casino man" to means the street boys, hooligans, hoodlums, and thugs (agents of the politicians) 
who usually disrupt, rig and cart away ballot boxes. This assertion is further supported by the penultimate line of the extract:

... or if tribes fear the ribs of Peace

Consequently, the action of these "area boys" often results in tribal crisis impeding the peace of the land as often the case in Africa. Furthermore, in a similar direction, the poet deviates in stanza one and four by the use of hyphenation to break the lexical item into two parts: "Paper Weight" (line three) and "tanta - listing" (line ten) in stanza one and "command-ants" in line three, stanza four. The hyphenated lexical item - "tanta - listing" in stanza one is for emphasis. It is used as an adjective to premodify "tongue". This implies that politicians pretend and unfaithfully deceive people to give empty promises to the people.

$$
\begin{aligned}
& \text {... failed matadors who bite } \\
& \text { their brother's earlobes. } \\
& \text { and proclaim love } \\
& \text { in a twist of tanta- } \\
& \text { lising tongues... }
\end{aligned}
$$

Moreover, the last stanza of the poem shows the poet's ability to play on words. The word "commandant" means an officer who is in charge of a military organization or establishment such as prison or soldiers during the war. But the poet hyphenates this word - "command - ant" to reduce its significance. The political leaders, during the military regime in Nigeria, are seen as commandants who are authoritarian and guilty of mismanagement, the poet reduces them to "ants".

$$
\begin{aligned}
& \text {... the canning command } \\
& \text { ants are waiting.. } \\
& \text { the Bullet is waiting } \\
& \text { to cast its bloody vote } \\
& \text { for heroes and fools. }
\end{aligned}
$$

The "Bullet" as used above is an instance of graphological deviation. This is because the use of capital letter "B" is unconventional here. The deviation is to show emphasis and to describe and compare the leaders with bullet whose act is to penetrate and kill or destroy good things and innocent souls. The bullet, in this regards, refers to politicians whose selfishness and greed is to manipulate election and at the end wait "to cast the bloody vote for heroes and fools" (reference to the last sentence of the extract).

\subsection{Graphological Internal Norm Deviation Analysis}

There is a distinction between internal and external graphological deviations. Linguists see external deviation as a form of deviation from norms external to the text. In Remi Raji's Webs of Remembrance, Bound to remember establishes a norm by representing each line of the poem with more than one lexical items, from stanza one up to stanza seven, but violates this norm in stanza eight, line four by representing the line with a single lexical item "grieved". The poet foregrounds the line to show the extent of his pain, woe, agony, etc. The word "grieved" means great sadness...

no water runs where the Niger flows

no fish swims where the Benue berths

my spirit is..

grieved.

i see rodents still...

So, out of the twenty eight lines, only one line has just one lexical item, which gives $1 / 28$ X 100/1 = 3.57\%.

The poet, from the above extract, decides to separate the lexical verbal item "grieved" away from its auxiliary "is" in lines three and four in the stanza to show and emphasize the feeling of the persona which is disheartening and sadness.

Similarly, the device of representing a line with a lexical item is also seen in "Malediction for a maximum ruler". The poet foregrounds stanza three, line eight by placing a lexical item "Dangerously" at the center of the stanza - this adverbial phrase captures the degree of the evils, atrocities and injustices these African leaders have 
committed and still perpetrating. The likes of Idi Amin (Uganda), Samuel Doe (Liberia) and Mobutu Sese Seko (Republic of Congo), Gadafi (Libya), Hosni Mubarak (Egypt) are sets of such rulers:

...oh yes, I tried to believe

that his bones now simmer

in Dante's sulfuric region

broiling in the tutorial vice

of Amin-Bokassa-Doe-Sese Seko School

they say the emperor is dead

but his symbols dangle

dangerously

his horsemen still rides.

In this stanza, out of twelve lines there, only just one line has one lexical item, which gives $1 / 12$ X 100/1= 8.3\%.

Furthermore, there is, another graphological internal deviation in the last stanza of the poem where the poet represents the last stanza of the poem in capital letters.

\section{HERE ROTS NEBUCHADNEZZAR FOREVER \\ KIND OF LOOTERS, HE WROTE HIS NAME \\ IN BLOOD, ON RIVERS OF BLAZING SHAME \\ HERE LIES THE CURSE FOREVER!}

While the preceding stanzas are written in the normal form, the poet foregrounds this stanza because he wants the message to be clear and bold. He makes a biblical allusion to Nebuchadnezzar whom the African leaders took after, and who is a good example of a despotic ruler. This graphological internal deviation is written boldly to attract reader's attention thus informing, educating and reminding them of the consequences of bad rulership.

Also, in the last stanza of "An African voting game," the poet begins the stanza in capital letters thereby creating graphologically, an internal norm. So, the poet begins each stanza in capital letters, but violates this norm in stanza four by beginning the stanza in small letters:

$$
\begin{aligned}
& \text { in the body work } \\
& \text { of your soap box } \\
& \text { the coming command- } \\
& \text { ant are waiting... }
\end{aligned}
$$

This means out of four stanzas here, he only deviates in one stanza, which is $1 / 4 \mathrm{X} 100 / 1=25 \%$

The poet adopts this method to reflect the social and political immoralities of our leaders. The poet gives a specific situation, election period, where leaders go around mobilizing hoodlums and "area boys", to disrupt the voting centres, disfranchise eligible citizens from voting, carting away ballot boxes, etc. This immoral posture informs the internal deviation of stanza three, which depicts departure from the usual norms or ways of doing things.

In "St. clinton's song", the poet uses internal graphological deviation in the fourth stanza, line four, by foregrounding the line with capitalization:

$$
\begin{aligned}
& \text { if I were Clinton } \\
& \text { i'd write my name in labial fluids } \\
& \text { i would quote myself in verse } \\
& \text { EVEN PRESIDENTS HAVE PRIVATE LIVES } \\
& \text { as Jefferson Johnson Nixon and Reagan } \\
& \text { and Kennedy that romp in the mating game }
\end{aligned}
$$

The poet foregrounds this line for emphasis. The line is written in capital letters and boldly because the poet wishes to state that everybody has his/her shortcomings. Therefore, attention should not be directed to African 
leaders alone. He cites the case of the former American President, Bill Clinton, who is expected to serve as a leader with good examples for people to emulate.

In addition, the internal deviation in stanza four, the poet uses another internal graphological deviation in stanza six to show a distinction between the first five stanzas and the sixth stanza. The first five stanzas of the poem begin with adverbial clause:

\section{if I were Clinton}

These fronting adverbials in the first five stanzas and the sudden change of the structure in stanza six, to the first person singular pronominal item "I" shows the change from the implied author to real author. The poet suddenly directs the message to himself moving from presumption to reality, specifying the personality and identity:

$$
\text { I am the people of scandals... }
$$

He metaphorically refers to himself as the father of immorality.

It is also noted that the deviation here, like the preceding one, has a low percentage, it is one out of six stanzas: $1 / 6$ X $100 / 1=16.67 \%$

\section{Conclusion}

This study has undertaken a graphostylistic analysis of poetry of a selected modern Nigerian Poet. The selected poems are those in the anthology of Webs of Remembrance by Remi Raji. In the process of the study, we identified, analyzed and interpreted the various graphological tactics deployed by the modern poet to convey his messages. The study revealed from the six selected poems in the anthology, webs of Remembrance, that a new linguistic framework of graphostylistics, using the graphonological devices and resources is capable of illuminating and exposing the communicative goals and intentions of Poetic genre as an instance of language use.

In a nutshell, the analysis of these poems shows that the graphostylistic tactics of punctuation, capitalization, lower cases of letters, hyphen and so on are tactically deployed to capture the themes of apprehension, bewilderment, socio-political vices, injustice, oppression, corruption, domination and selfishness of the political leaders both at home and abroad, and indirectly express the need for revolutionary change (Marxist ideology), and hope that awaits the oppressed. (Reference to the author's note) In addition, it is noted that the internal deviation enjoys a low percentage throughout the poem as follows:

In Bound to Remember, we have: 3.57\%

In Malediction for a maximum ruler, we have: $8.3 \%$

In Africa voting game, we have: $25 \%$

In St. Clinton's song, we have: $16.67 \%$

This confirms the fact that "deviation" in general, in whatever form, is neither a cherished norm nor even a virtue in African society. This presupposes that the Africans only admire normalcy, virtuous practice and cherish their traditions and cultural practice.

\section{References}

Adegbite, Wale. (1994). Teaching English Prosodic Features to Nigerian Secondary School Pupils. Ife Journal of Theory and Research in Education, 4(1\& 2), 82-94.

Akmajian, Advian, \& et al. (Eds.). (2003). Linguistis: An Introduction to Language and Communication. New Delhi: Prentice Hall.

Aremo, William Bolaji. (1995). An Introduction to English Sentence (Vol. 1). Ibadan Caltop.

Awonuga, Christopher Olatunji. (1988). Linguistic Stylistics as a method of Literary interpretation: in Ife Studies in English Language. Massachusetts M.I.T Press.

Ayeomoni, Moses Omoniyi. (2004). The role of Stylistics in Literary Studies. In Lekan Oyeleye, \& Moji Olateju (Eds.), Readings in Langauge and Literature. Ile-Ife OAU Press.

Ayeomoni, Moses Omoniyi. (2005). A linguistic-Stylistics Investigation of the language of Nigerian Political Elites. Nebula, 2(2), 153-168.

Ayodabo, Ola. (2003). A Pragma-Stylistic study of forms and functions of Hedges in a Presidential Media Chat on NTA. An unpublished Ph.D Dissertation. University of Ilorin, Ilorin. 
Barry, Peter. (1995). Beginning Theory. Manchester: Manchester University Press.

Bresler, Charles. (2003). Literary Critics: An Introduction. London: Pearson.

Cambridge. (2002). Cambridge International Dictionary of English. Cambridge Unversity Press.

Chapman, Raymond. (1973). Linguistics and Literature. An Introduction to Literary Stylistics. London: Edward Arnold Publisher Ltd.

Chatman, Seymour. (1965). A theory of Meter. The Hague Mouton, Janua Linguarum.

Chomsky, Noam. (1970). Methodological Preliminaries. Aspect of the Theory of Syntax, 26-40.

Culicover, Peter. (1976). Syntax. New York: Academic Press.

Dare, S. A. (1991). Some approaches to the study of Style. In Oyegoke, L. (Ed.), Undergraduate Text in English Language and Literature (pp. 59-71).

Enkvist, Nil. (1964). Linguistic and Style. London: Oxford University Press Ltd.

Fowler, Roger. (Ed.). (1955). Style and Structure. London Rutledge and Kegan Pauls.

Fowler, Roger. (Ed.). (1986). Linguistic Critic. New York: Oxford University Press.

Halliday, Micheal Alexander Kirkwood, Angus McIntosh, \& Peter Strevens. (1964). The Linguistic Sciences and Language Teaching. London: Longmans.

Halliday, Michael Alexander Kirkwood. (1973). Exploring in the Function of Language. London: Edward Arnold.

Halliday, Micheal Alexander Kirkwood. (1976). System and Function in Language. Selected Papers edited by Gunther Kress. London: Oxford University Press.

Lawal, Adebayo. Aspects of Stylistic Theory and the Implication for Practical Criticisms. Journal of Stylistics in Theory and Practice, 25-47.

Leech, Geoffrey, \& Short, Mick. (1981). Style in Fiction. New York: Longman.

Lyons, John. (1981). Language and Linguistics. Cambridge University Press.

Mick Short, \& Geoffrey Leech. (1981). Style in Fiction. Longman Publishing Group.

Mukarovsky, Jan. (1932). Structural Poetics and Esthetics. USA: Duke University Press.

Osundare, Niyi. (2008). Days. Paperback: Ibadan, Nigeria.

Remi, Raji. (2001). Webs of Remembrance. Ibadan: Kraft Books Secondary Sources.

Short, Mick, \& Geoffrey, Leech. (1981). Exploring the Language of Poems, Plays and Prose. London: Longman.

Short, Mick. (1982). Stylistics and the teaching of literature: A portrait of the artist as a young man. In Roland Carter, \& Deirdre Burton (Eds.), Language and Literature (pp. 179-192). London: Allen \& Unwin.

Short, Mick. (1996). Exploring the Language of Poems, Plays and Prose. New York: Longman.

Tomori, Sunday Hezekiah Olu. (1977). The Morphology and Syntax of Present-Day English. London: Heinemann.

Turner, George William. (1973). Stylistic. England: Penguine Books.

Wales, Katie. (1991). A Dictionary of Stylistics. New York: Longman. 


\section{Appendixes}

Appendix 1.

\section{Bound to remember}

no water runs where the Niger flows

no fish swims where the Benue berths

my spirit is grieved, my grief is long like the rivers

i will not forgive I will not forget

i will be like God vengeance of truth

I will be thunder in the kidneys of liars

i will remember the tadpole head

of our terrible tales i will remember

the necklace of the albatross

hanging in the hearts of butchers

i will the bomb-game goon

i will remember his landmines of lies

i will remember the oasis of blood

no water runs where the Niger flows

no fish swims where the Benue berths

my spirit is grieved, my grief is long like the rivers

how will i forget the pain

when i remember the knife and see the scar?

no water runs where the Niger flows

no fish swims where the Benue berths

my spirit is...

grieved.

i see rodents still

i see bats flying above the flood

and i smell the odour in the air

which betrays the anus of the tribe

dressed but naked like prostitutes.

oh, i am grieved beyond forgetting... 
Appendix 2.

\section{Malediction for a maximum ruler}

"And for those who still suffer from the shadows and knocks of tyrants, this poem is recommended as morning meal, daily; preferably, the last stanza should be read aloud, with or without 'Amen'”.

1.

Write the poem, the Wind hailed me

Chew the bones and drink the blodd

of emperors in your appetite of writing

Churn that bloodless art

and chant no more evil

about the beast; feel no more nightmares

when next you hear the creeping rumours

of minted monies exhumed.

Sing your harmless song, o poet

and ask no extinct questions

about Tyrannosaurus

and the lost incense of fats...

2.

But I tried most in vain

to kill this knifing nightmare

I tried in vain to slash the cursing tongue

Not to remember the emperor of scars

who forgot his brains

in a luncheon of prostitutes... I tried in vain

not to seek foolish questions like

who held the treasury-key

when Cyclops burnt the State House

or who sprinkled the soil with seeds

with threats of self-succession.

3.

Oh yes, I tried to believe

that his bones now simmer

in Dante's sulfuric region

broiling in the tutorial vice

of Amin-Bokassa-Doe-Sese Seko School.

They say the emperor is dead

aBut his symbols dangle

Dangerously

his horsemen still ride

their own mothers widows sisters

they hoist their pride

in hides of pretence... 
4.

in the emperor's trail

let there be a conference of curses

in the tyrant's praise

let cannons of fake biographies be burnt

and on the terrible soil

which swallowed the pig

let an epitaph of piss be written:

HERE ROTS NEBUCHADNEZZAR FOREVER

KING OF LOOTERS; HE WROTE HIS NAME

IN BLOOD, ON RIVERS OF BLAZING SHAME

HERE LIES THE CURSE FOREVER!

Appendix 3.

\section{An African voting game}

(i)

And the ballot boxers spring

into the ring again

flyweight, superweight, paper-

weight of bantam

bricks of tricks

ballot boxers in numbers game

failed matadors who bite

their brothers' earlobes

and proclaim love

in a twist of tanta-

lising tongues.

They jive

into the ring

again, a multitude

of banter and brawl

waiting

on the wings

of foul fists.

(ii)

We have opened our bellies

where the jackals strut, we have asked

a fester of flies to heal our wounds

we have ordained the village thief

as the banker of barns and trinkets.

(iii)

Now, if the boxer bites below the belt? 
Or if the referee throws a deadly fist

And gives a casino man the knife to stab the Bank?

Or if tongues bite themselves in brawls?

Or if tribes tear the ribs of Peace?

Or if...

(iv)

in the body work

of your soup box

the conning command-

ants are waiting...

the Bullet is waiting

to cast its bloody vote

for heroes and fools.

Appendix 4.

\section{St. clinton's song}

if i were Clinton

i would clinch one more victory

in the lewinskian lap of tender nights

if i were Clinton

i would bite the apple again

and blame saddam the serpent of Iraq

i would blame castro the eunuch of Havana.

if $\mathrm{i}$ were Clinton

i would dare the jury \& clone the truth

i a doublespeak of pleasant lies

i would make the world

watch my tie and not my lie.

if i were Clinton

i'd write my name in labial fluids

i would quote myself in verse

EVEN PRESIDENTS HAVE PRIVATE LIVES

as Jefferson Johnson Nixon and Reagan

and kennedy that romp in the mating game.

if i were Clinton

i would ride on everest of emotions

adonis romeo cupid crucified

in the republican envy

of beasts and barbarians

i shall rise again and spin 
on the legendary statue of simple lechery.

I am

the people of scandals

I do not blame

the smooth negligee

of monica's winks, I kiss the oval script

of $\mathrm{x}$-rated lives

and wait for death

by public circumcision.

But as I go through this gallow of lust

I ask the private saint among the rabble:

Cast the celibate stone and let be die!

Appendix 5.

\section{Light must break}

\section{(To all Africa's children of hope)}

Timeless Congo, timeless Nile

The Niger and the Benue

Zambezi and the Limpopo

Rivers all, witness our woes.

The songs I hear are powered

by xylophones of darkness

and remnants of cannibal kings

who dance in the sun

who litter the statue book

with regimes of pain..

The songs I hear come

from feathery violence of hawks

from red throats of courteous hyenas

whose hearts pant after the people

like panthers on prowl...

\section{Timeless Congo, timeless Nile}

The Niger and the Benue

Zambezi and the Limpopo

Rivers all, witness our woes.

The suns of independence are dying

before the wink of days

Dreams are drenched

Before the wink of days 
Dreams are drenched

in a fountain

of lies

Dreams are doused

by a whirl wind of emperors

on banks of gruesome rivers...

Timeless Congo, timeless Nile

The Niger and the Benue

Zambezi and the Limpopo

Rivers all, witness our woes.

Timeless darkness, timeless lies!

But one dawn

After the pogrom of dreams

One surprised dawn...

Light must break

The shadows of the dead

The lost and the silenced

The spirit of the devoured

Will rise again

From new wombs.

Timeless Congo, timeless Nile...

Light must break the back

Of darkness

Light must break

Into redolent chants

Of merry rivers

Light must flow

In the heart of the Equator

Light, must grow

On the lips of sonorous hope.

Light must break. Break. 